IRSH 67 (2022), pp. I-7 doi:I0.1017/S0020859022000074

(C) The Author(s), 2022. Published by Cambridge University Press on behalf of Internationaal Instituut voor Sociale Geschiedenis. This is an Open Access article, distributed under the terms of the Creative Commons Attribution licence (https://creativecommons.org/licenses/by/4.o/), which permits unrestricted re-use, distribution, and reproduction in any medium, provided the original work is properly cited.

\title{
Introduction: Regulation and Domestic Service in Colonial Histories
}

\author{
VICTORIA H A S K N S \\ Faculty of Education and Arts, University of Newcastle \\ Callaghan, New South Wales, Australia \\ E-mail: victoria.haskins@newcastle.edu.au \\ SAMITA SEN (1) \\ Trinity College, University of Cambridge \\ Cambridge, CB2 I TQ, United Kingdom \\ E-mail: samitasen@yahoo.co.uk
}

\begin{abstract}
This essay introduces the Special Theme on regulation and domestic service in colonial societies. It provides a brief overview of the key themes of domestic service and regulation in the history of colonial states, and reflects upon the ways in which the colonial past is deployed in contemporary calls for the regulation of domestic work by the state, to secure the rights and protections of present-day workers as modern, free subjects. We note that, while much more work needs to done on this subject, current scholarship suggests that the status of the domestic worker and the extent of regulation in colonial contexts was historically unclear and often ambivalent. The three articles that constitute the Special Theme are then discussed in turn, to highlight the important insights, both empirical and theoretical, they offer to our deeper understanding of this complex history.
\end{abstract}

The colonial state is associated with regimes of regulation. In almost all colonial societies, a composite of laws, policies, and practices aimed at overseeing diverse populations has been characteristic of their historical development. 
As its history is one of regulatory encounters - attempts, successes, slippages, resistances, and renegotiations - the colonial state can be closely interrogated through its own juridical archive of laws and regulations. Here, the colonial archive reveals more about the nature of colonial rule than it does about the colonized, betraying the precarity of colonial control. In this context, the "domestic" emerges as a highly charged ideological category of imperial governmentality. ${ }^{\mathrm{T}}$ The reproductive labour of domestic servants implicated in both the formation of categories of rule and hierarchies of difference within colonial societies, cannot be set aside from the imperatives of the colonial/ imperial project; and the history of regulation of domestic service in colonial societies is complicated and multi-dimensional.

This is a history with important resonances for the present situation regarding domestic labour and its regulation. From the turn of the twentieth century, we have witnessed the expansion of domestic work employment across many different countries, and, indeed, the rise of a global economy of domestic labour, with what might be considered "neo-colonial" features. Such features of this contemporary global economy of domestic labour include the heavy dependence upon the availability of cheap migrant labour, significant pools of which are sourced from former colonial sites. ${ }^{2}$ In the receiving countries (sometimes themselves also former colonies), the presence of migrant domestic workers poses challenges in terms of their categorization as, generally, temporary non-citizens. The direction of recent efforts to secure and protect the rights of domestic workers has been to introduce the regulation of their occupation. Thus, the International Labour Organization's Convention I 89 of $20 \mathrm{II}$ and its Recommendation 20I of the same year referred to the suite of options available to national governments in dealing with domestic workers' employment (namely, "laws, regulations or collective agreements" 3 ), to define and manage conditions of domestic employment and to recognize and protect domestic workers' rights as occupational workers. The key issue in many studies of the rights and conditions of domestic workers in the present world is what kind of state regulatory apparatuses exist, and should exist, with regard to the nature and location of their employment.

Twenty-first-century campaigns to secure regulatory protection for domestic workers often deploy an "effective discursive strategy" that, implicitly or explicitly, compares the position of the contemporary domestic workers

\footnotetext{
${ }^{I}$ Ann Laura Stoler, Along the Archival Grain: Epistemic Anxieties and Colonial Common Sense (Princeton, NJ, 2009), p. 23.

${ }^{2}$ B.W. Higman, "An Historical Perspective: Colonial Continuities in the Global Geography of Domestic Service", in Victoria K. Haskins and Claire Lowrie (eds), Colonization and Domestic Service: Historical and Contemporary Perspectives (New York, 2015), pp. 19-37.

3 International Labour Organization, Decent Work for Domestic Workers: Convention I 89 and Recommendation $20 \mathrm{I}$ at a Glance (Geneva, 201 I), p. I7.
} 
with colonized and enslaved servants of the past. ${ }^{4}$ These historical workers are seen as having been excluded from regulatory labour provisions. In today's definitions and characterizations of paid domestic work, there is a tension between the emphasis on the labour contract (promoted as a means of defining a "worker") and metaphorical references to servitude, and with its entanglement in colonial histories of slavery and enforced labour. Such uses of the past have been a feature of twentieth-century labour rhetoric more generally, characteristic of both employer-driven reformist movements and domestic workers' organized activism throughout the twentieth century. History thus continues to reiterate the tensions and contradictions following from the ambiguities of the colonial regulatory project. Moreover, these rhetorical strategies tend to erase the agency of domestic workers both in the past and in the present, in order to bring them under the special and watchful care of the modernizing state, in ways that workers themselves may find restrictive of their autonomy or alienating. ${ }^{5}$

It is urgent, then, to clearly and carefully historicize domestic work within the context of race, slavery, and colonialism. The first phase in the interest in the history of domestic service, from the I970s, focused on Europe and was associated with the emergence of feminist scholarship on histories of the home and domesticity. In this phase, the specificity of the intersection of gender and class drove historical scholarship. In the context of "new imperial histories" from the I990s, domesticity and domestic work has acquired a new political valence. This burgeoning literature on colonial domestic service, however, remains highly uneven. While there are still large gaps in our understanding of modes and extent of regulation of domestic work in the metropole, in the case of the colonies, scholarship is much more fragmented. For instance, so far as colonies in South and Southeast Asia are concerned, there is very little known of the colonial, let alone pre-colonial, history of domestic work. All colonial states took an interest in managing and regulating relations in domestic service in one way or another. It is clear, however, that there were significant differences among the different colonial regimes in this respect.

The current state of scholarship suggests that colonial states approached the "domestic" in highly ambiguous and even contradictory terms. On close inspection, the status and legal position of domestic servants in the past, whether colonial and otherwise, remains somewhat undefined, and certainly contestable. As part of their modernizing rhetoric, colonial regimes intervened in relationships of dependency that were central to pre-colonial domesticity.

${ }^{4}$ Jennifer N. Fish, “A Contemporary Perspective: 'Picking the Fruit from the Tree'. From Colonial Legacy to Global Protections in Transnational Domestic Worker Activism”, in Victoria K. Haskins and Claire Lowrie (eds), Colonization and Domestic Service: Historical and Contemporary Perspectives (New York, 201 5), pp. 328-349, 330.

5 See Shireen Ally, From Servants to Workers: South African Domestic Workers and the Democratic State (Ithaca, NY, 2009), pp. I I-I6. 
The British, for instance, invested heavily in demonstrating a formal transition from slavery and/or compulsory servitude to contractual systems. Thus, contract was posited as the central principle of master-servant legislation. However, the substance of existing coercive instruments of control was built into contracts in their variety of forms. The presence of forced or coercive practices in labour arrangements, even those governed by contract, was distinctively colonial. Differences between metropolitan and colonial labour regimes were sustained by arguments around the supposed lack of development in colonial societies, but also by a range of exceptionalist arguments, which hinged on imperial characterization of the peculiarities of colonial labour, often following an explicit racialized logic. And the contradictory consequences of colonial labour regulations in this period sometimes became especially evident in the case of domestic workers. In the domestic realms of the colonies in particular, the hesitant introduction of contract laws was balanced by a robust refusal to intervene in practices of dependencies and bondage. As a result, one of the crucial features of paid domestic labour in many post-colonial societies today is the simultaneity of various modes of labour, such as slavery, servitude, and contract. As in the colonial, so in the post-colonial period, domestic service employment has been both inside and outside the ambit of the state.

This Special Theme offers three focused historical articles on the colonial state regulation of domestic service. It proceeds from a double-panel workshop organized in Belfast, Northern Ireland, in 20I8, within the European Social Science History Conference, and under the auspices of the European Research Council funded project, Servants Past (20I 5-20I8), led by one of the contributors, Nitin Sinha. The workshop and these articles that have been produced from it address a period of transition from the eighteenth to the twentieth century. In this period, state regulation of domestic work has waxed and waned with multiple trajectories in different parts of the world, imbricated in categories such as class, race, and gender. The unprecedented labour mobilization in the eighteenth and nineteenth centuries in many parts of the world, including the colonies, also drew domestic service into its ambit, which grew as an avenue of employment for the rural poor, especially women, and was linked with patterns of national, regional, and international migration. However, regulation of domestic workers often followed patterns quite different from those of other forms of labour. There are thus questions both of patterns in common and exceptional to the generality of labour regulation where domestic work is concerned.

The articles that follow explore how the colonial state expressed its relationships to both colonized and colonizer, servant and master, subject and citizen, through regulation or lack thereof. In this regard, the intervention of the colonial regime, particularly through the legal system, in the arrangements between employers and domestic workers in the private home, was crucial. But, even beyond the home, and beyond the colony itself, colonial regulation could 
reach out to manage the lives and conditions of colonial domestic servants and their employers. Moreover, the question of regulation of domestic workers reached beyond the state, to broader social regulations embedded in relationships of race, class, and gender. Thus, the question of regulation of domestic workers is heard on multiple registers.

Race is a constitutive category here, although readers will find this point made more explicit in some of the essays than in others. There can be no doubt that race was a primary category for colonial capitalism and its management hinged on the control of the domestic sphere. The regulation of the domestic worker also connects the colonial ordering of race to the making of class in the metropole. Servants were the "subaltern gatekeepers of gender, class, and racial distinctions", who transgressed by their very presence. ${ }^{6}$ They were the objects of anxiety both in the metropole and the colonies, and the trajectories of difference are indicative of global politics of race in the period.

The first article, by the scholar who initiated this project, Nitin Sinha, focuses upon South Asia, examining long-term processes of the colonial state's management of domestic workers from the late eighteenth century. This is pioneering work since we know next to nothing about regulation of domestic work in colonial India.

Sinha explores the long history of both the regulation and the registration of domestic workers. Sinha shows how a pendulum swung between attempts to regulate the master-servant relationship through the legal system, and efforts to secure controls over domestic workers via registration systems. In India, the colonial state initiated systems of registration for many categories of urban labour, including domestic workers, in the I760s, and discussions on its mode and desirability continued up to the I 8 Ios. A system of legal regulation allowing for the criminal prosecution of wayward servants, imposed from I 8 I9 through to I 86I, saw an abeyance in demands for domestic worker registration, but on repeal such pressures again mounted. Discussions and campaigns for greater control over servants would continue unresolved throughout the rest of the century. As Sinha notes, the servant was cast as "a potential criminal" and policing was seen as "the most important tool" of control. In the twentieth century, the Indian state, both colonial and postcolonial, has remained deeply ambivalent about regulating domestic servants. On the one hand, there has been hesitation to intervene in the private world of elite and middle-class homes, which has resulted in exempting domestic workers from most labour laws; on the other hand, a continued association with criminality has pushed greater involvement of the police in regimes of surveillance today.

\footnotetext{
${ }^{6}$ Ann Stoler, Carnal Knowledge and Imperial Power: Race and the Intimate in Colonial Rule (Berkeley, CA, 2002), p. I33.
} 
If Sinha shows us how deeply and historically embedded the colonial connection is between state systems of regulation, policing, and domestic servitude, Claire Lowrie's article draws our attention to the historiographical effects of such connections. Lowrie's study moves us forward to the twentieth century and to colonial Singapore. She examines three cases where Chinese domestic workers in Singapore were accused of murder between I910 and 1930, against a backdrop of rising anti-colonial agitation. She elaborates how, in the absence of any other kind of colonial government regulation, Chinese men working as servants interacted with the colonial state only as perpetrators (and sometimes victims) of violent crimes. In this guise, they come into the historian's field of vision, through the traces that remain in the legal archives of the colonial state. The court cases - unusual and atypical as they are - provide significant and illuminating insights into the otherwise inaccessible private and everyday lives and relationships of these workers. They appear as more than just dependent workers in the home, but rather as complex individuals negotiating their way through a larger, interconnected social world.

In these two articles, both authors address issues of state regulation at the interface of the domestic and the public. Sinha suggests that the colonial state's efforts to control wages and implement a system of registration are conceived in the context of a bazaar economy with multiple and overlapping occupations. Lowrie's three cases focus on domestic workers embroiled in the state's criminal investigative and judicial systems, demonstrating the mutual constitution of law and the domestic relations. They suggest ways in which "servants" partake in domestic relations and the implications of individuation of domestic workers in relation to the state. The third article addresses this latter question frontally.

Raffaella Sarti concludes this Special Theme with her article on the unstable position of domestic workers during the revolution in France and its colonies. Sarti elaborates and explains the significance of defining citizenship for domestic workers in the foundational moment of the French revolution, exploring the entangled and complex relationship between colonial power relations and domestic service in the metropole. Seen from the vantage of domestic workers' struggles, the French Revolution entailed crucial disavowals and exclusions by gender, race, and slavery. Sarti notes the parallel exclusions of enslaved people and domestic servants. Slavery in the French colonies was not finally abolished until I 848 , and, even then, former slaves transitioned into bonded labour. Significantly, only the men were enfranchised. Even in France itself, only male domestic workers acquired new rights, and then only formally and for a short period. Given that the proportion of women among domestic workers increased in the nineteenth century, these processes converged into the feminization of dependency. The disenfranchisement of domestic servants, and their exclusion from the categories of citizenship, was a product of a complex of race, gender, and dependence that served as a 
formidable barrier to equality. Thus, the rights promised by the revolution failed those who performed reproductive labour.

Read together and in conversation with each other, it is possible to move towards an articulation of the complexities of colonial regulation of domestic service. While efforts of colonial states to regulate domestic service and servants were diverse and varied, ambiguous and contradictory, and patchy and uneven across a range of sites, we can see the emergence of patterns around the management of race. These workers in the home posed threats and challenges to colonial projects, which provoked a range and variety of regulatory experiments, all of which tended to constrain and restrict the independence of domestic workers. Regulation - or calls for regulation - in colonial history proved fertile ground for creating categories of subjecthood. We see how within changing and diverse regimes of colonial labour regulation, however underpinned by discourses of protection and even freedom, the desire to control and to differentiate the domestic worker from other workers remained a constant. This history urges that we are cautious in our demands for sustained state interventions and regulations to protect and uphold the dignity and rights of present-day domestic workers. 